\title{
ARTICLE
}

\section{Morpho-meiotic study in Mentha Iongifolia from cold des- ert regions of Lahaul-Spiti and adjoining areas of Himachal Pradesh (India)}

\author{
Devendra Kumar Srivastava ${ }^{1, *}$, Manjit Inder Singh Saggoo ${ }^{2}$ \\ 1'Department of Botany, Akal College of Basic Sciences, Eternal University, Baru Sahib, Himachal Pradesh-173101, India \\ ${ }^{2}$ Department of Botany, Punjabi University Patiala, Punjab-147002, India
}

\begin{abstract}
A morpho-meiotic study of wild Mentha longifolia (L.) L. (Lamiaceae) is presented from the nine populations (Kukumsari, Zero-point, Kishori, Tosh, Kasol, Key, Tiling, Mudh and Darcha) in and around the cold desert regions of Lahaul-Spiti of Himachal Pradesh. Present work is needful effort to fill the gap of morpho-meiotic (morphological and cytological) knowledge in M. longifolia growing in high altitude regions. Meiotic study revealed the different chromosome counts in these populations as $n=12$, $\mathrm{n}=12+0-3 \mathrm{~B}$ and $\mathrm{n}=9$. Presence of $\mathrm{B}$-chromosome in the species is reported for the first time from the study area and it reflects inter-population variation in five important descriptors (such as a nature of whole plant, stem, leaves, inflorescences and pollen) with 17 sub-descriptor states and occurrence of B-chromosomes. Present study reflects the existence of $M$. longifolia at diploid (2x) level based on base numbers $x=12$ and $x=9$. Acta Biol Szeged 62(2):131-139 (2018)
\end{abstract}

\author{
KEY WORDS \\ cytological \\ morphological \\ Mentha longifolia \\ chromosome counts \\ B-chromosomes \\ ARTICLE INFORMATION \\ Submitted \\ 21 October 2018 \\ Accepted \\ 15 November 2018 \\ *Corresponding author \\ E-mail: devsrivastv@gmail.com
}

\section{INTRODUCTION}

Mentha longifolia (L.) L. (Lamiaceae), known well as Habek mint or Horse mint, is an aromatic perennial and tomentose herb that grows mostly in semi-shady places on moist soils (Ahmad et al. 2011; Shinwari et al. 2011). It is indigenous to Eastern Europe, Middle East, South and North Africa, Saudi Arabia and it grows wild in cold desert regions of Himachal Pradesh and in North West Himalayan belt of India. Fresh leaves and stems are mostly used for flavouring in 'salads' and cooked foods (Facciola 1990). Like other members of the genus Mentha L., it is used in domestic herbal remedy, being valued especially for its antiseptic properties and beneficial effects on digestion (Karousou et al. 2007). Leaves are the chief source of essential oils, enriched in compounds like menthol, menthone, pulegone, piperitone oxides, certain monoterpenes, carvone, flavonoids, limonene and dipentene (Gulluce et al. 2007; Al-Rawashdeh 2011; Ayshath et al. 2016); and are widely used in food, beverages, flavour, cosmetics and pharmaceutical industries (Džamić et al. 2010; Bhargava 2016; Mahmoudi et al. 2016).

The species is an extremely variable taxon as large number of varieties and sub-species are reported in it (Sobti 1962) and highly variable with respect to habit, plant size, shape, denticulation and hairiness of leaves, spike length and flower colour (Aswal and Mehrotra 1994; Sarić-Kundalić et al. 2009). The information collected from the online data bases (IPCN of the $\mathrm{w}^{3}$ TROPICOS database of Missouri Botanical Garden, Chromosome Web Watch of Japan, PhytoKaryon of University of Patras, Chromosome Counts Database, etc.), research journals and literatures (Darlington and Wylie 1955; Kumar and Subramanian 1986; Khatoon and Ali 1993; Rice et al. 2015 , etc.) indicate that the species is equally variable in terms of chromosome number as $2 \mathrm{n}=18$ to 144 (Srivastava 2012; Malik et al. 2017). So far, morpho-meiotically, $M$. longifolia has not been studied from the India. Thus, present study deals with morpho-meiotic investigation of $M$. longifolia collected from the high-altitude location in and around the cold desert regions of Lahaul-Spiti of Himachal Pradesh (India). Present work is needful effort to fill the gap of morpho-meiotic (morphological and cytological) knowledge in $M$. longifolia growing in high altitude regions.

\section{MATERIALS AND METHODS}

Plant material for the present study comprised of nine populations of $M$. longifolia from Lahaul-Spiti and adjoining area of Himachal Pradesh. Plants were studied and collected in Kukumsari, Zero-point, Kishori, Tosh, Kasol, 
Key, Tiling, Mudh and Darcha localities. Morphological characters were noted in the field and data were recorded at 50\% flowering stage. Voucher specimens are deposited in the herbarium, Department of Botany, Punjabi University, Patiala, India (PUN). For evaluation, five important descriptors were considered, i.e. plant, stem, leaf, inflorescence and pollen. Each descriptor was further studied under different sub-descriptor states which were accessed statistically. The sub-descriptor states included were plant habit (HB), height $(\mathrm{PH})$, habitat $(\mathrm{HBT})$, stem hairiness (SLH), stem branching (SB), intermodal length (INL), petiole length (PL), leaf shape (LSp), dorsal (DP) and ventral pubescence (VP), presence or absence of leaf denticulation (DLP), intensity of denticulation in leaf margin (DLM), spike length (SL), flower colour (FC), flowering period (FP), pollen size (PS) and pollen fertility percentage (PF\%).

For meiotic analysis the appropriate stage of young inflorescences were collected between 9.00 to 11.00 a.m. and fixed in Carnoy's fixative (6:3:1 = ethanol:chloroform: glacial acetic acid, v/v) for $24 \mathrm{~h}$., after which they were transferred to $70 \%$ alcohol and stored at $4{ }^{\circ} \mathrm{C}$. Pollen mother cells (PMCs) were obtained through standard squash technique in $1 \%$ acetocarmine. Several freshly prepared and permanent slides were carefully examined from each population to determine the chromosome number at different stages and meiotic abnormalities. Pollen stainability in glycerol: acetocarmine (1:1) was used to estimate pollen viability. For micro-photography an Eclipse 80i microscope system (Nikon) was used.

\section{RESULTS}

Presently, morpho-meiotic study was carried out in nine population of M. longifolia L. growing in cold desert regions of Himachal Pradesh. Morphologically, populations of $M$. longifolia were recorded with large variation in their field characters (sub-descriptor states) and clearly revealed the existence of four morphotypes viz. morphotype $\alpha, \beta, \gamma$ and $\delta$. (Table 1) Scoring for the morphological characters, meiotic chromosome number $(2 n)$ and ploidy in each population is given in Table 1 . Chromosome number (2n) records in M. longifolia and cytological information of genus Mentha L. from India and rest of the world is provided in Table 2 and Table 3.

\section{Morphological study}

Among the studied populations of four morphotypes in M. longifolia L., two morphotypes, i.e. $\alpha$ and $\beta$ were erect

Table 1. Morphological characters in various morphotypes of M. longifolia.

\begin{tabular}{|c|c|c|c|c|c|c|c|}
\hline \multirow{2}{*}{\multicolumn{2}{|c|}{ Characters }} & \multicolumn{3}{|c|}{ Morphotype $\alpha$} & Morphotype $\beta$ & Morphotype y & Morphotypes $\delta$ \\
\hline & & \multirow{2}{*}{$\begin{array}{l}\text { Without } \\
\text { B-chromosomes } \\
\text { Kukumsari }\end{array}$} & \multirow{2}{*}{$\begin{array}{l}\text { With } \\
\text { B-chromosomes } \\
\text { Zero-point, Kishori }\end{array}$} & \multirow{2}{*}{$\begin{array}{l}X_{1} \\
-\end{array}$} & \multicolumn{3}{|c|}{ Without B-chromosomes } \\
\hline & Populations & & & & Tosh, Kasol & Key, Tiling, Mudh & Darcha \\
\hline \multirow{3}{*}{ Plant } & $\mathrm{HB}$ & Erect & Erect & Erect & Erect & Semi-erect & Semi-erect \\
\hline & $\mathrm{PH}(\mathrm{cm})$ & $60-150$ & $70-150$ & $60-150$ & $40-80$ & $35-50$ & $45-70$ \\
\hline & HBT & $\begin{array}{l}\text { Moist } \\
\text { \& shady places }\end{array}$ & $\begin{array}{l}\text { Moist } \\
\text { \& open slopes }\end{array}$ & Moist places & $\begin{array}{l}\text { Moist places } \\
\& \text { road sides }\end{array}$ & $\begin{array}{l}\text { Dry slopes \& banks } \\
\text { of Spiti river }\end{array}$ & $\begin{array}{l}\text { Dry Slope near- } \\
\text { Bhaga tributary }\end{array}$ \\
\hline \multirow{3}{*}{ Stem } & SLH & Non-hairy & Non-hairy & Non-hairy & Less hairy & Densely hairy & Densely hairy \\
\hline & SB & $\begin{array}{l}\text { Rarely } 3 \text { to } \\
4 \text { branched }\end{array}$ & $\begin{array}{l}\text { Rarely } 2 \text { to } \\
4 \text { branched }\end{array}$ & Branched & Highly branched & Unbranched & Unbranched \\
\hline & $\mathrm{INL}(\mathrm{cm})$ & $4.6-7.7$ & $4.2-8.1$ & 5.72 & $3.4-5.2$ & $4.4-8.2$ & $4.5-7.6$ \\
\hline \multirow{6}{*}{ Leaf } & $\mathrm{PL}(\mathrm{cm})$ & $1.3-3.2$ & $1.4-2.9$ & 1.73 & $1.4-2.5$ & $0.6-0.8$ & $1-1.8$ \\
\hline & $\mathrm{LSp}$ & Lanceolate & Lanceolate & Lanceolate & Oblong & Oblong & Oblong \\
\hline & $\mathrm{DP}$ & $(+)$ low & $(+)$ low & $(+)$ low & $(+)$ low & $(+)$ high & $(+)$ high \\
\hline & VP & - & - & - & $(+)$ low & - & $(+)$ low \\
\hline & DLP & + & + & + & + & + & \pm \\
\hline & DLM & $\begin{array}{l}\text { Conspicuously } \\
\text { toothed }\end{array}$ & $\begin{array}{l}\text { Conspicuously } \\
\text { toothed }\end{array}$ & $\begin{array}{l}\text { Conspicuously } \\
\text { toothed }\end{array}$ & $\begin{array}{l}\text { Moderately } \\
\text { toothed }\end{array}$ & $\begin{array}{l}\text { Moderately } \\
\text { toothed }\end{array}$ & Wavy \\
\hline \multirow{3}{*}{ Inflorescence } & $\mathrm{SL}$ & $9-18$ & $7-15$ & 12.11 & $6-14$ & $2.5-4.5$ & $2.5-4.1$ \\
\hline & $\mathrm{FC}$ & Purple & Purple & Purple & Purple & Purple & Cream white \\
\hline & $\mathrm{FP}$ & July-Sept. & July-Sept. & July-Sept. & June-Aug. & July-Aug & July-Aug \\
\hline \multirow{4}{*}{ Pollen } & $\mathrm{PS}(\mu \mathrm{m})$ & $25.80 \times 25.56$ & $26.11 \times 25.80$ & - & $26.35 \times 25.82$ & $24.85 \times 24.74$ & $25.06 \times 24.88$ \\
\hline & PF (mean \%) & 100 & 73.89 & & 94.25 & 93.04 & 93.33 \\
\hline & $2 \mathrm{n}$ Count & 24 & $24+(1 / 2-3) B$ & - & 24 & 24 & 18 \\
\hline & Ploidy & $2 x$ & $2 x$ & $2 x$ & $2 x$ & $2 x$ & $2 x$ \\
\hline
\end{tabular}

$X_{1}=$ congruent mean value for morphotype $a$. 

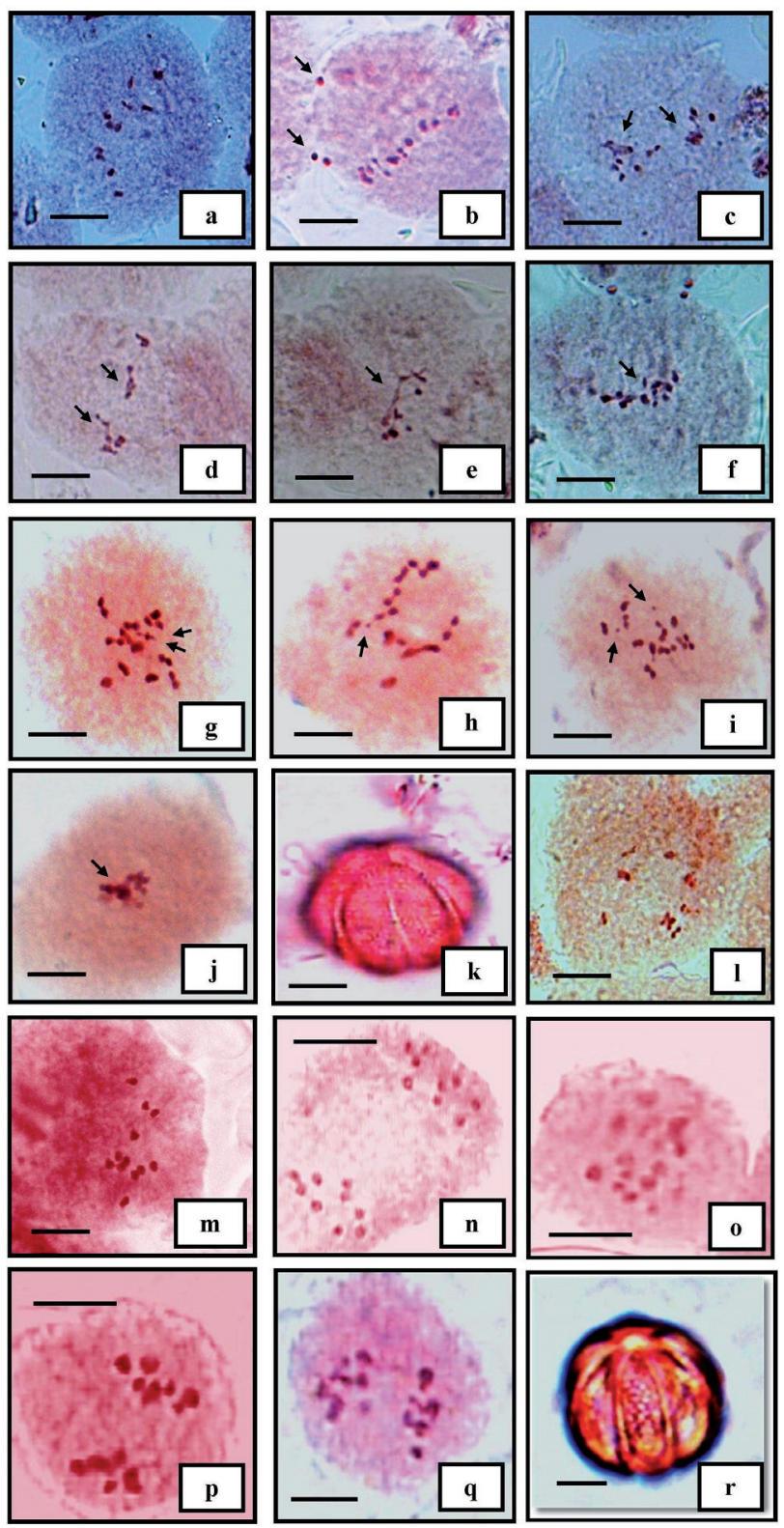

Figure 1. Mentha longifolia (L.) L. Morphotype a: (a) PMC showing $12_{\|}$at $\mathrm{M}-\mathrm{l}$; (b) PMC with $12_{\| 1}+3 \mathrm{~B}$ at M-l; (c-f) PMCs showing the inter-bivalent connections and chromosome stickiness at M-l; (g) PMC with a pair of 2B-chromosomes $\left(12_{11}+2 \mathrm{~B}\right)$ at $\mathrm{M}-\mathrm{l}$; (h) PMC with single B-chromosome $\left(12_{11}+1 \mathrm{~B}\right)$ at $\mathrm{M}-\mathrm{l}$; (i) PMC showing $12_{\|}+2 \mathrm{~B}$ at $\mathrm{M}-\mathrm{l}$; (j) PMC with chromosome stickiness at $\mathrm{M}-\mathrm{l}$; (k) A fertile pollen. Morphotype $\beta$ : (I) PMC showing $12_{\|}$at M-I. Morphotype $\mathrm{y}$ : (m) PMC with $12_{\|}$at M-I. Morphotype $\delta$ : (nq) PMC with 9:9 chromosome distribution at A-I; (r) A fertile pollen. Scale bar $=10 \mu \mathrm{m}$.

while other two $(\gamma$ and $\delta)$ were semi-erect in habit (HB) (Table 1). Average value of plant height $(\mathrm{PH})$ varies from 60 to $150 \mathrm{~cm}$ in the populations of morphotype $\alpha\left(\mathrm{X}_{1}=\right.$ 60-150 cm; PUP55036, PUP54935, PUP54929), which is followed by the plants of morphotype $\beta(40-80 \mathrm{~cm}$; Tosh $=$
PUP55023, Kasol = PUP54937), morphotype $\delta(45-70 \mathrm{~cm}$; Darcha $=$ PUP55031) and morphotype $\gamma($ Key $=$ PUP54936, Tiling $=$ PUP55033, $\mathrm{Mudh}=$ PUP55004) Plants of all the morphotypes except that of morphotype $\delta$ (which were growing on dry slope near Bhaga River tributary), were reported from moist and open shady conditions.

Stem hairiness (SLH) was absent in the population of morphotype $\alpha$ while presents in others morphotype populations. Branching habit (SB) was observed as entire in the population of morphotype $\beta$ and it is moderate in morphotype $\alpha$ with 2/3-4 branches per plants, while two morphotypes, i.e. $\gamma$ and $\delta$ were unbranched (Table 1). Average $\left(X_{1}\right)$ of variation values in inter-nodal length (INL) was less differentiable among the populations of the studied morphotypes $\alpha\left(\mathrm{X}_{1}=5.72 \mathrm{~cm}\right.$; ranged $\mathrm{b} / \mathrm{w}$ 4.6-7.7 \& 4.2-8.1), $\gamma(4.4-8.2 \mathrm{~cm})$ and $\delta(4.5-7.6 \mathrm{~cm})$, but it was lesser in range for the plant population of morphotype $\beta(3.4-5.2 \mathrm{~cm})$.

For the character of petiole length (PL) higher value was reported in the plants of morphotype $\alpha\left(X_{1}=1.73 \mathrm{~cm}\right)$, while it was lower in range for the plants of morphotype $\gamma(0.6-0.8 \mathrm{~cm})$ and intermediate in plant population of morphotype $\beta(1.4-2.5 \mathrm{~cm})$ and $\delta(1-1.8 \mathrm{~cm})$. Leaves in all the morphotypes were oblong in shape (LSp) except in morphotype $\alpha$ were they were lanceolate. Leaf margin varies in denticulation (DLM) as sparse (more or less wavy in outline) in morphotype $\delta$, moderate in morphotype $\beta$ and $\gamma$ to conspicuously toothed in morphotype $\alpha$. For sub-descriptor state of leaf pubescence, the character of pubescence was almost present on dorsal surface (DP) of leaves of all the available morphotypes (dense and high in $\gamma$ and $\delta$ morphotypes), but absent from the ventral surface (VP) in plant populations of morphotype $\alpha$ and $\gamma$.

Among the studied accessions of morphotypes, range of flower spike lengths (inflorescence; SL) varies as 2.5-4.1 $\mathrm{cm}, 2.5-4.5 \mathrm{~cm}, 6-14 \mathrm{~cm}, 7-15 \mathrm{~cm}$ and $9-18 \mathrm{~cm}$ in morphotype $\delta, \gamma, \beta$, morphotype $\alpha$ (plants with B-chromosomes) and morphotype $\alpha$ (plants without B-chromosomes), respectively; whereas flower colour (FC) was either light purple (morphotype $\alpha, \beta$ and $\gamma$ ) or cream white (morphotype $\delta$ ) in colour. Flowering period (FP) varies marginally in all the available morphotypes with the difference of one month only and it starts in month of June (morphotype $\beta$ ) or July (morphotype $\alpha, \gamma$ and $\delta$ ) and remains in blooming condition between mid-July to August. No major differences were observed in pollen size (PS) measurement within the studied morphotypes (Table 1).

\section{Cytological study}

Morphotype $\alpha$ : Meiotic studies in the plants of these morphotype revealed the presence of two different chromosome numbers. Plants belonging to Kukumsari population were reported with $2 \mathrm{n}=24$ at M-I (Fig. 1a), while PMCs 
in the plants of Zero-point and Kishori populations were observed to show B-chromosomes along with haploid chromosome count of $n=12$ (Fig. 1b-g). The plants with and without $\mathrm{B}$-chromosomes were indistinguishable in this morphotype (i.e. $\alpha$ ). The number of B-chromosomes was observed to vary from 0 to 3 in the plants of population of Zero-point area (Fig. 1b-f), while it varied between 1 to 2 in Kishori population (Fig. 1g-i).

PMCs in the plants of Zero-point population were observed with inter-bivalent connections (37.50\%) and chromosome stickiness (13.20\%; Fig. 1c-f). Inter-bivalent connections (18.33\%) and chromosome stickiness (7.50\%) was also reported in few PMCs of the plants collected from Kishori population (Fig. 1j). Nearly 100\% pollen fertility (Fig. 1k) was recorded in Kukumsari population while in plants of Zero-point and Kishori population the average pollen fertility was below $76.30 \%$.

Morphotype $\beta$ : Numerous PMCs in both the populations of this morphotype revealed the chromosome count of $2 \mathrm{n}$ $=24$ at M-I (Fig. 11). Meiotically the plants were normal and were recorded with high (above 90\%) pollen fertility.

Morphotype $\gamma$ : Meiotic analysis in the plants collected from the Key, Tiling and Mudh populations confirms the presence of $2 \mathrm{n}=24$ chromosome at M-I (Fig. $1 \mathrm{~m}$ ). Meiotic course in these plants was normal and pollens grains were cent-percent fertile ( $>90 \%)$.

Morphotype $\delta$ : The plants belonging to Darcha population exhibited a different meiotic count. Several PMCs at different stages of meiosis were observed with chromosome count of $n=9$ (Fig. 1n). The plants of this population were perfectly normal in their meiotic course (Fig. 1o-q) and were recorded with high ( $>90 \%)$ pollen fertility (Fig. 1r).

\section{DISCUSSION}

\section{Morphological variation}

Morphological variation within a species is inductive of taxonomic heterogeneity and is considered as one of the fundamental factors in the process of evolutionary changes (Blinova 2012). These variations are not only helpful in establishing the connectivity of populations but also associated with the adaptability and evolution ability of taxa. It is well known fact that intraspecific morphological variations are more common in the widespread species than in the local or endemic ones (Darwin 1839; Whittakar and Fernandez-Palacios 2007). Species growing in different types of habitats also shows variations in morphological characters that are accounted for by differences in ecological conditions (Valen 1965; Stout et al. 2015). Morphological adaptations among plants to different kind of climatic and environmental conditions make them more diverse and evolved. Such plasticity in the genetic and morphological characters is more prominent among the individuals of different populations than among the members of the same population (Svensson 1983; Śpaniel et al. 2008). In general, morphological variations could happen due to the differences in the environmental conditions (Jones and Geber 1999; Petru et al. 2006; Stout et al. 2015), geographical boundaries (White 1971), selection and genetic drift (Abdelkrim 2005; Stuessy et al. 2006).

Variations of morphological characters among different members (i.e. species) of genus Mentha L. are quite common. In the presently studied species, intraspecific morphological variation was reported in different cytotypes of M. longifolia L. $(\mathrm{n}=9,12)$. Intraspecific morphological variation in the populations of $M$. longifolia (Table 1) might be attributed to the variation in chromosome numbers $(\mathrm{n}=9,12)$ and abnormal meiotic course, as it has been reported earlier in large number of flowering plants, e.g., Centaurea phrygia (Koutecký 2007), Centaurea stoebe (Śpaniel et al. 2008), Ranunculus parnassifolius (Cires et al. 2009), Agrimonia sp., Geranium wallichianum, Ranunculus hirtellus and Vicia rigidula (Kaur and Singhal 2010a). The presence or absence of B-chromosomes did not affect the morphological characteristics as the plants of $M$. longifolia with or without B-chromosome are indistinguishable in most of their descriptor states.

Morphological diversity among the species of genus Mentha is great. Due to high polymorphism, the number of species in the genus has been a matter of speculation for many years. Several features have been used in the past to examine the diversity of species using morphological (Malinvaud 1880) and cytological (Harley and Brighton 1977; Singh and Sharma 1986) aspects. Natural interspecific hybridization occurs with high frequency in Mentha species which may also led to morphological variation within the species. For example, cytological studies in $M$. spicata $(=M$. lavaegata) shows two cytotypes with $2 \mathrm{n}=36(\mathrm{x}=9)$ and $48(\mathrm{x}=12)$ chromosomes, which differ only (except molecular) on the basis two aspects, i.e. presence or absence of non-secreting trichomes and chemical data (Gobert et al. 2002). Based on cytological and karyological data Harley and Brighton (1977) suggested the M. spicata $(\mathrm{n}=24)$ as a hybrid of $M$. suaveolens $(\mathrm{n}=12)$ and M. longifolia $(\mathrm{n}=12)$.

Several varieties have been proposed by different authors in M. longifolia based on morphological and/ or cytological differences, e.g., M. spicata var. longifolia, $M$. sylvestris var. royleana and $M$. longifolia var. royleana, M. longifolia ssp. capensis, M. longifolia spp. longifolia, etc. (Mukerjee 1940; Harley and Brighton 1977; Raizada and Saxena 1978; Chambers and Hummer 1994; Tarimcilar and Kaynak 2004). But currently most of these varieties 
Table 2. Chromosome number (2n) count in M. longifolia (L.) L. from India and rest of the world (outside India).

\section{*Mentha longifolia (L.) L.}

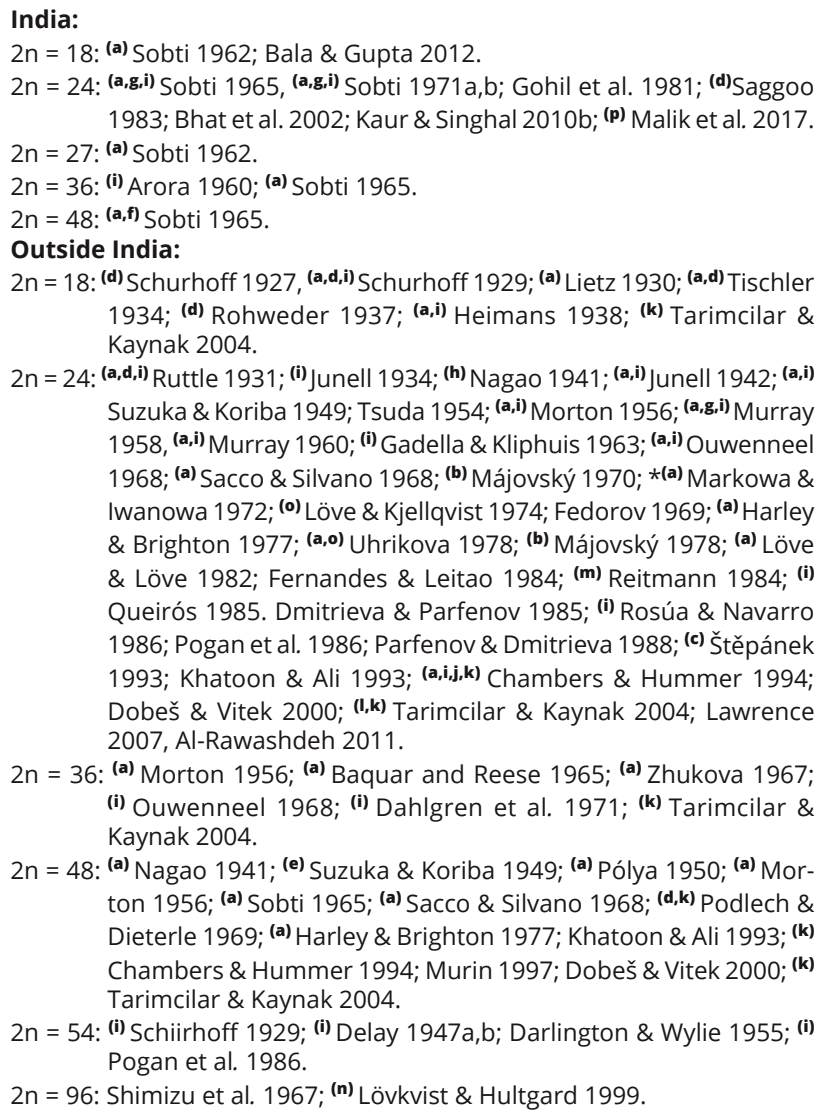

$2 n$ = 48: (a) Nagao 1941; (e) Suzuka \& Koriba 1949; (a) Pólya 1950; (a) Morton 1956; (a) Sobti 1965; (a) Sacco \& Silvano 1968; (d,k) Podlech \& Dieterle 1969; (a) Harley \& Brighton 1977; Khatoon \& Ali 1993; (k) Chambers \& Hummer 1994; Murin 1997; Dobeš \& Vitek 2000; (k) Tarimcilar \& Kaynak 2004.

2n = 54: (i) Schiirhoff 1929; (i) Delay 1947a,b; Darlington \& Wylie 1955; (i) Pogan et al. 1986.

2n = 96: Shimizu et al. 1967; (n) Lövkvist \& Hultgard 1999.

*Note: Chromosome counts in many publications were reported with synonyms of Mentha longifolia (L.) L.

\section{Synonyms:}

a M. Iongifolia (L.) Hunds.; ' M. Iongifolia (L.) Nath.; ${ }^{\mathbf{c}}$ M. Iongifolia (L.) L. subsp. longifolia; ${ }^{\mathbf{d}} M$. sylvestris Linn.; ${ }^{\mathbf{e}} M$. longifolia (sylvestris) ${ }^{\mathbf{f}} M$. sapida Tausch.; ${ }^{\mathbf{g}}$ M. rotundifolia L.; ${ }^{\mathbf{h}}$ M. rotundifolia; ${ }^{\mathbf{i}}$ M. rotundifolia (Linn.) Huds.; j M. longifolia subsp. hymalaiensis Briq. \& $M$. longifolia subsp. capensis (Thunb.) Briq. \& M. longifolia subsp. polyadena (Briquet) Briq.; ${ }^{\mathbf{k}}$ M. longifolia subsp. longifolia; ' $M$. longifolia var. typhoides; ${ }^{\mathbf{m}} M$. longifolia subsp. $\times$ M. suaveolens; ${ }^{\mathbf{n}}$ M. aquatica var. aquatic; ${ }^{\circ} \mathrm{M}$. longifolia; ${ }^{\mathbf{p}} \mathrm{M}$. Iongifolia $\mathrm{L}$.

are treated as sens. lat. under same synonym of $M$. longifolia (L.) L. to cover the large range of variations (Aswal and Mehrotra 1994). From the present study area variation in hairiness of stem; size, shape and hairiness of leaves; spikes and flowers were also reported by Aswal and Mehrotra (1994). In the present case intensive screening of populations of the species from Lahaul-Spiti area revealed four morphotypes $(\alpha, \beta, \gamma$ and $\delta$ ) occupying different locations. It seems that the phenotype of the population is greatly influenced by altitudinal range and topography. The populations of the species collected from dry temperate
(Key, Tiling, Mudh and Darcha) areas show high tomentum (DP and VP) and almost woolly outlook while those of moist temperate locations (Kukumsari, Zero-point, Kishori, Tosh and Kasol) were less hairy.

The variants in the taxa are distributed in the different ecological and environmental conditions. The flowering period among the different populations varies marginally with the difference of one month. It indicates that the variation might be due to ecological preferences as suggested in other flowering plants (Korner 1999; Parker et al. 2003; Andi et al. 2011).

Morphological characteristics are the consequences of the effect of various ecological factors on the genotype of the species. Stebbins (1950) suggested that intraspecific variations of morphological characters are dependent upon the environmental modifications, genetic recombination and mutations.

\section{Cytological illustration}

Presence of $2 n=24$ in the present taxa agrees with the previous reports from India and outside (Table 2). Whereas the count of $2 \mathrm{n}=18$ in Darcha population (morphotype $\delta)$ also confirms the previous reports from India and from the other parts of the world (Table 2). However, the present study is the first report about the presence of $\mathrm{B}$ chromosome in this species $(\mathrm{n}=12+0-3 \mathrm{~B})$.

Nearly all the described species of the genus are known cytologically (Table 3). The genus exhibits a wide range of chromosome numbers $(2 \mathrm{n}=10$ to 144 ; highest in $M$. piperita L.; Lutkov et al. 1966; Singh 1995) which indicate the polybasic nature of the genus with base numbers $\mathrm{x}=$ $5,6,9,10,12$ and $x=13$. The base number $x=9$ and 12 are the most common in distribution (Table 3). Morton's report (Morton 1973; Chambers and Hummer 1994) of $2 \mathrm{n}=10$ for $M$. pulegium from the Liège Botanical Garden makes the lowest base number $\mathrm{x}=5$ in the genus. The base numbers $\mathrm{x}=7$ and 8 are also suggested in the genus. But, true diploids $(2 \mathrm{n}=14,16)$ based on these base numbers are not yet reported in nature. Singh (1995) suggested x $=12$ as a secondary base number for the genus. While, Harley and Brighton (1977) suggested $\mathrm{x}=12$ as the ancestral (primary) base number for the Menth $\mathrm{L}$. This view was also supported by Bhat et al. (2002) and Lawrence (2007). However, literature confirms the polybasic nature of the genus with wide range of polyploids (100\%) and variable reports based on different base numbers. Such a great variability in base number may be due to frequent interspecific hybridization, which makes it cytologically a complex genus.

In India nearly 13 Mentha species (including hybrids) are cytologically available. The species $M$. longifolia is already being reported with $2 \mathrm{n}=18,24,27,36$ and $2 \mathrm{n}=$ 48 from different parts of the world (Table 2), it represent 
Table 3. Cytological information on the worldwide and India basis in genus Mentha L.

\begin{tabular}{|c|c|c|c|c|c|c|c|c|c|c|c|}
\hline & \multirow{2}{*}{\multicolumn{2}{|c|}{ Species }} & \multirow[b]{3}{*}{$\begin{array}{c}\text { **Total } \\
\text { cytotypes }\end{array}$} & \multirow[b]{3}{*}{$\begin{array}{c}\text { 2n chromosome } \\
\text { counts } \\
\text { (number of species) }\end{array}$} & \multicolumn{6}{|c|}{ Number of Species } & \multirow[b]{3}{*}{$\begin{array}{l}\star \star \star \text { Base } \\
\text { number }\end{array}$} \\
\hline & & & & & \multicolumn{5}{|c|}{ Polyploidy } & \multirow[b]{2}{*}{$\begin{array}{c}\text { Aneuploidy or with } \\
\text { more than one } \\
\text { base number }\end{array}$} & \\
\hline & *Total & $\begin{array}{l}\text { Cyto- } \\
\text { logically } \\
\text { counted }\end{array}$ & & & Only $2 x$ & Total & $\begin{array}{c}\text { Intraspecific } \\
\text { polyploidy } \\
\text { (base number) }\end{array}$ & Level & $\%$ & & \\
\hline World & 20 & A59 & 123 & $\begin{array}{l}\text { в10 (1), } 12(1), 18(9), \\
20(2), 24(19), 26(1), \\
27(1), 30(1), 32(1), \\
36(14), 40(2), 42(3), \\
46(1), 48(11), 49(1), \\
50(1), 54(5), 60(3), \\
64(5), 66(2), 68(1), \\
72(14), 74(1), 78(1), \\
84(2), 90(2), 92(1), \\
96(7), 98(1), 105(1), \\
108(2), 120(2), 122 \\
(1), 132(2), 140(1), \\
\text { с144(1) }\end{array}$ & - & A59 & $\begin{array}{l}2(8), 2(9), 2 \\
(10), 12(12)\end{array}$ & $2 x$ to $12 x$ & 100 & 7 & $\begin{array}{c}(5),(6), 9 \\
10, \underline{12} \& 13\end{array}$ \\
\hline India & 2 & A13 & 23 & $\begin{array}{l}18(1), 24(2), 32(1), \\
36(4), 40(1), 46(1), \\
48(4), 64(1), 68(1), \\
72(2), 84(1), 90(1), \\
96(1), 122(1), c 144(1)\end{array}$ & - & A13 & A3 (12) & $\begin{array}{c}2 x, 4 x, 6 x \\
8 x, 12 x\end{array}$ & - & 2 & $8,9,10, \underline{12}$ \\
\hline
\end{tabular}

* Excluding hybrids/ varieties and sub-species of Mentha. ** Cytotypes = Numbers of different chromosome counts within a same species. *** Common ones bolded; doubtful ones in parenthesis; more frequently available ones bolded and underlined.

A: Number includes cytologically worked out wild and exotic / cultivated as well as hybrid species of the genus. The higher number of cytologically known species then the taxonomically recorded taxa is due to synonyms, illegitimate, invalid or unresolved names. (Major sources = Hooker 1885; Mukerjee 1940; Darlington \& Wylie 1955; Fedorov 1969; Saggoo 1983; Kumar \& Subramaniam 1986; Khatoon and Ali 1993; Aswal and Mehrotra 1994; Harley et al. 2004; Srivastava 2012; Rice et al. 2015; Index to Plant Chromosome Numbers: http://www.tropicos.org/Project/IPCN/; Chromosome Counts Database: http://ccdb.tau.ac.il/; The Plant List: http://www.theplantlist.org/; The International Plant Names Index: https://www.ipni.org/).

B: Lowest 2n = $10(x=5)$ in M. pulegium (Morton 1973; Chambers and Hummer 1994).

C: Highest $2 n=144(x=12)$ in M. piperita (Lutkov et al. 1966; Singh 1995).

the intraspecific chromosome variability at $x=9$ and 12 . Diploid nature of this species with $\mathrm{x}=9$ and $\mathrm{x}=12$ was supported by many workers (Schurhoff 1929; Morton 1956; Murray 1960; Harley and Brighton 1977; Lawrence 2007; Al-Rawashdeh 2011). Thus, present observation of $2 \mathrm{n}=18$ and $2 \mathrm{n}=24$ (or $2 \mathrm{n}=24+1 / 2-3 \mathrm{~B}$ ) in $M$. longifolia are seems to be at diploid $(2 \mathrm{x})$ level which are based on $\mathrm{x}=9$ and $\mathrm{x}=12$.

\section{ACKNOWLEDGMENTS}

The authors are grateful to the Himachal Pradesh Public Work Department (HPPWD) for providing rest/ circuit houses during the explorations. Thanks are also to Head, Department of Botany, Punjabi University, Patiala (Punjab, India) for necessary laboratory facilities.

\section{REFERENCES}

Abdelkrim M (2005) Long sequence time series analysis of Moroccan ecosystem dynamics. Ph.D. Thesis, Clark University, Worcester, Massachusetts, USA.
Ahmad I, Ahmad MSA, Ashraf M, Hussain M, Ashraf MY (2011) Seasonal variation in some medicinal and biochemical ingredients in Mentha longifolia (L.) Huds. Pak J Bot 43 (01):69-77.

Al-Rawashdehm IM (2011) Molecular taxonomy among Mentha spicata, Mentha longifolia and Ziziphora tenuior populations using the RAPD technique. JJBS 4(2):63-70.

Andi SA, Nazeri V, Zamani Z, Hadian J (2011) Morphological diversity of wild Origanum vulgare (Lamiaceae) in Iran. Iran J Bot 17(1):88-97.

Arora CM (1960) New chromosome report. Bull Bot Sur India 2:305.

Aswal BS, Mehrotra BN (1994) Flora of Lahaul-Spiti (A Cold Desert in the North-West Himalaya). Bishen Singh Mahender Pal Singh Publication, Dehradun, India. 466-522.

Ayshath ASAR, Sanjiv K, Kamath JV (2016) Cardioprotective effect of Mentha longifolia against cyclophosphamide induced cardiotoxicity in rats: a biochemical, electrocardiographic and histopathological study. Int J Pharm Pharmaceut Sci 8(9):214-217.

Bala S, Gupta RC (2012) IAPT/ IOPB Chromosome data XIV. Taxon 61(6):1336-1345.

Baquar SR, Reese G (1965) Cytotaxonomische und gaschromatographische Untersuchungen an norddeutschen 
Mentha-Formen. I. Teil: Die Pharmazie 20:159-168.

Bhargava S (2016) Mosquito repellency potential of the essential oil from Mentha spp. Int J Pharm Pharmaceut Res 6(3):509-522.

Bhat S, Maheshwari P, Kumar S, Kumar S (2002) Mentha species: in vitro regeneration and genetic transformation. Mol Bio Today 3:11-23.

Blinova IV (2012) Intra- and interspecific morphological variation of some European terrestrial orchids along a latitudinal gradient. Russ J Eco 43(2):111-116.

Chambers HL, Hummer KE (1994) Chromosome counts in the Mentha collection at the USDA: ARS National Clonal Germplasm Repository. Taxon 43(3):423-432.

Cires E, Cuesta C, Peredo EL, Revilla MA, Fernández PJA (2009) Genome size variation and morphological differentiation within Ranunculus parnassifolius group (Ranunculaceae) from calcareous screes in the Northwest of Spain. Plant Sys Evol 281:193-208.

Dahlgren R, Karlsson T, Lassen P (1971) Studies on the flora of the Balearic Islands I. Chromosome numbers in Balearic angiosperms. Bot Not 124:249-269.

Darlington CD, Wylie AP (1955) Chromosome Atlas of Flowering Plants. Allen and Unwin, London, UK.

Darwin CR (1839) Narrative of the surveying voyages of His Majesty's Ships Adventure and Beagle between the years 1826 and 1836, describing their examination of the southern shores of South America, and the Beagle's circumnavigation of the globe. Journal and remarks. 1832-1836. Henry Colburn, London.

Delay C (1947a) Recherches sur la structure de noyaux quiescents chez les Phanérogames. Rev Cytol Cytophysiol Végét 9(1-4):169-222.

Delay C (1947b) Recherches sur la structure de noyaux quiescents chez les Phanérogames. Rev Cytol Cytophysiol Végét 10(1-4):103-229.

Dmitrieva SA, Parfenov VI (1985) Kariologicheskaja kharakteristika nekotorykh vidov poleznykh rastenij flory Belorussii. Izvestiia Akademii Nauk Belorusskoi SSR, Ser Biol Nauk 6:3-8.

Dobeš C, Vitek E (2000) Documented Chromosome Number Checklist of Austrian Vascular Plants. Verlag des Naturhistorischen Museums Wien, Vienna.

Džamić AM, Soković MD, Ristić MS, Novaković M, Grujićjovanović S, Tešević V, Marin PD (2010) Antifungal and antioxidant activity of Mentha longifolia (L.) Hudson (Lamiaceae) essential oil. Bot Serb 34(1):57-61.

Facciola S (1990) Cornucopia: A Source Book of Edible Plants ( $6^{\text {th }}$ ed.). Kampong Publications, Vista, CA, USA.

Fedorov AA (1969) Chromosome Numbers of Flowering Plants. Academy of Natural Sciences of the USSR, Leningrad, USSR.

Fernandes A, Leitão MT (1984) Contribution à l'étude cytotaxinomique des Spermatophyta du Portugal XVIII-
Lamiaceae. Mem Soc Broter 27:27-75.

Gadella TWJ, Kliphuis E (1963) Chromosome numbers of flowering plants in the Netherlands. Acta Bot Neerland 12:195-230.

Gobert V, Moja S, Colson M, Taberlet P (2002) Hybridization in the section Mentha (Lamiaceae) inferred from AFLP markers. Am J Bot 89(12):2017-2023.

Gohil RN, Ashraf M, Raina R (1981) Cytotaxonomical conspectus of the flora of Kashmir II. Chromosome numbers of 51 dicotyledonous species. Herb Hung 20(3):43-49.

Gulluce M, Sahin F, Sokmen M, Ozer H, Daferera D, Sokmen A, Polissiou M, Adiguzel A, Ozkan H (2007) Antimicrobial and antioxidant properties of the essential oils and methanol extract from Mentha longifolia L. ssp. longifolia. Food Chem 103:1449-1456.

Harley RM, Atkins S, Budantsev AL, Cantino PD, Conn B J, Grayer R, Harley MM, de Kok R, Krestovskaja T, Morales R, Paton AJ, Ryding O, Upson T (2004) Labiatae. In Kubitzki K, ed., The Family and Genera of Vascular Plants. Volume VII. Springer Verlag, Berlin Heidelberg, 167-275.

Harley RM, Brighton CA (1977) Chromosome number in the genus Mentha L. Bot J Linn Soc 74:71-96.

Heimans J (1938) Chromosomes in the genus Mentha. Chrom Bot 4:389-390.

Hooker JD (1885) The Flora of British India. Volume IV (Asclepiadeae to Amarantaceae). Reeve L and Co Ltd, London.

Jonas CS, Geber MA (1999) Variation among populations of Clarkia unguiculata (Onagraceae) along altitudinal and altitudinal gradients. Am J Bot 86(3):333-343.

Junell S (1934) Zur Gynáceummorphologie und Systematik der Verbenaceen und Labiaten. Symb Bot Upsal 1(4):1219.

Junell D (1942) Mentha. In Löve A, Löve D, eds., Chromosome Numbers of Scandinavian Plant Species. Bot Not 42: 19-59.

Karousou R, Balta, M, Hanlidou E, Kokkini S (2007) Mints, smells and traditional uses in Thessaloniki (Greece) and other Mediterranean countries. J Ethnopharm 109(2):248-257.

Kaur D, Singhal VK (2010a) Chromosome number, meiosis and pollen fertility in Vicia rigidula Royle and V. tenera Grah. from cold regions of India. Cytologia 75:9-14.

Kaur D, Singhal VK (2010b) IAPT/IOPB Chromosome data 9 (IOPB column by Marhold K, Breitwieser I). Taxon 59(4):1298-1302.

Khatoon S, Ali SI (1993) Chromosome Atlas of the Angiosperms of Pakistan. Department of Botany, University of Karachi, Pakistan.

Körner C (1999) Alpine plant life: functional plant ecology of high mountain ecosystems. Springer, Berlin.

Koutecký P (2007) Morphological and ploidy level variation 
of Centaurea phrygia agg. (Asteraceae) in the Czech Republic, Slovakia and Ukraine. Folia Geobot 42(1):77-102.

Kumar V, Subramanian B (1986) Chromosome atlas of flowering plants of the Indian subcontinent I (Dicotyledons). Bot Surv India, Calcutta.

Lawrence BM (2007) Mint: the genus Mentha. Taylor and Francis, Boca Raton, London New York.

Lietz J (1930) Beiträge zur Zytologie der Gattung Mentha. Dissertation Universität Berlin 12:1-36.

Löve A, Kjellqvist E (1974) Cytotaxonomy of Spanish plants. IV. Dicotyledons: Caesalpinacea-Asteracea. Lagascalia 4(2):153-211.

Löve A, Löve D (1982) IOPB Chromosome number reports LXXXV. Taxon 31:344-360.

Lövkvist B, Hultgard UM (1999) Chromosome numbers in south Swedish vascular plants. Opera Bot 137:1-42.

Lutkov AN, Bulgakov SV, Beljaeva RG (1966) Allopolyploidy and interspecific hybridization of peppermints (Mentha piperita L.). Experimental polyploidy in plant breeding. Nauka, Novosibirsk Publication, Russia, 172-185pp.

Mahmoudi R, Katiraee F, Tajik H, Abbas A, Farshid, Fakhri O (2016) Inhibitory effect of Mentha longifolia L. essential oil against Listeria monocytogenes using transmission electron microscopy. Int J Vet Sci Res 2(1):014-017.

Májovský J (1970) Index of chromosome numbers of Slovakian flora (Part 1). Acta Fac Rerum Natur Univ Comen, Bot 16: 1-26.

Májovský J (1978) Index of chromosome numbers of Slovakian flora (Part 6). Acta Fac Rerum Nat Univ Comen Bot 26:1-42.

Malik RA, Gupta RC, Singh V, Bala S, Kumari S (2017) New chromosome reports in Lamiaceae of Kashmir (Northwest Himalaya), India. Protoplasma 254(2):971-985.

Malinvaud E (1880) Simple aperçu des hybrides dans le genere Mentha. Bull Soc Bot France 27:332-347.

Markowa ML, Ivanova P (1972) Karyologische Untersuchung der vertreter der Fam. Boraginaceae, Labiatae und Scrophulariaceae in Bulgarien. Izv Bot Inst (Sofia) 22:149-157.

Morton JK (1956) The chromosome numbers of the British Menthae. Watsonia 3:244-251.

Morton JK (1973) A cytological study of the British Labiatae (excluding Mentha). Watsonia 9:239-246.

Mukerjee SK (1940) A revision of the Labiatae of the Indian empire. Records of the BSI. Government of India press, Calcutta. 1-228pp.

Murin A (1997) Karyotaxonomy of some medicinal and aromatic plants. Thaiszia J Bot 7:75-88.

Murray MJ (1958) Evolution in the genus Mentha. Proceedings X. Int Cong Genet 2:201-202.

Murray MJ (1960) The genetic basis for a third ketone group of Mentha spicata L. Genetics 45:931-993.

Nagao S (1941) The number of chromosomes in some spe- cies and varieties of Mentha. J Sapporo Soc Agric Forest 32:28-36.

Ouweneel WJ (1968) Cytotaxonomic studies in the genus Mentha in the Nederlands. Proc Roy Netherlands Acad Sci C71:184-188.

Parfenov VI, Dmitrieva SA (1988) Kariologicheskaja kharakteristika predstavitelej flory sosudistykh rastenij Berezinskogo biosfernogo zapovednika. Zapov Belorussii Issl 12:3-8.

Parker JD, Christopher CC, Mark EH (2003) Beaver herbivory on aquatic plants. Oecologia 151:616-625.

Petrů M, Tielbörger K, Belkin R, Sternberg M, Jeltsch F (2006) Life history variation in an annual plant under two opposing environmental constraints along an aridity gradient. Ecography 29:1-9.

Pólya L (1950) Magyarországi növényfajok kromoszómaszámai II. Annal Biol Univ Debrecen 1:46-56.

Podlech D, Dieterle A (1969) Chromosomenstudien an Afghanischen pflanzen. Candollea 24:185-243.

Pogan E, Jankun A, Maslecka J, Wcisslo H (1986) Further studies in chromosome numbers of Polish angiosperms. Part XIX. Acta Biol Cracov Ser Bot 28:65-85.

Queirós M (1985) Números cromosómicos para a flora Portuguesa 86-103. Bolet Soc Broter 58:85-96.

Raizada MB, Saxena HO (1978) Flora of Mussoorie. Bishan Singh and Mahendra Pal Singh, Dehradun.

Reitmann K (1984) Karyologische Untersuchungen an der Mentha spicata - Gruppe (Lamiaceae). Tafeln Hausarbeit, Universität Graz. 14-45.

Rice A, Glick L, Abadi S, Einhorn M, Kopelman NM, Salman-Minkov A, Mayzel J, Chay O, Mayrose I (2015) The chromosome counts database (CCDB) - a community resource of plant chromosome numbers. New Phytol 206(1):19-26.

Rohweder H (1937) Versuch zur Erfassung der mengenmässigen Bedeckung des Darss und Zingst mit polyploiden Pflanzen. Ein Beitrag zur Bedeutung der Polyploidie bei der Eroberung neuer Lebensräume. Planta 27:501-549.

Rosúa JL, Navarro T (1986) Números Cromosomáticos de Plantas Occidentales, 329-336. An Jardin Bot Madrid 42(2):481-486.

Ruttle ML (1931) Cytological and embryological studies on the genus Mentha. Gartenbauwiss 4:428-468.

Sacco T, Silvano S (1968) On the cytotaxonomy of selected mints of the section "Spicatae" I and II. Mints with prevalent piperitenone oxide in the oil: Mentha rotundifolia (L.) Huds. var. bullata Briq., Mentha longifolia (L.) Huds. var. grandis Briq., M. longifolia (L.) Huds. var. typica Fiori. Allionia 14:177-198.

Saggoo MI (1983) Cytomorphological studies on plants of economic importance of Bicarpellatae from India. PhD Thesis, Department of Botany, Punjabi University, Patiala, Punjab (India). 
Šarić-Kundalić B, Fialová S, Dobeš C, Ölzant S, Tekelová D, Grančai D, Reznicek G, Saukel J (2009) Multivariate numerical taxonomy of Mentha species, hybrids, varieties and cultivars. Sci Pharm 77:851-876.

Schürhoff PN (1927) Zytologische Untersuchungen über Mentha. Beitr Biol Pflanzen 15:129-146.

Schürhoff PN (1929) Zytologische und genetische Untersuchungen an Mentha und ihre Bedeutung für die Pharmakognosie. Arch Pharm Berlin 267:515-526.

Shimizu S, Udo S, Sacco T (1967) Contribute allo studio citotassonomice e chimico della "Mentha viridis" (L.) L. cultivar X "lavanduliodora”. Allionia 13:215-219.

Shinwari ZK, Sultan S, Mehmood T (2011) Molecular and morphological characterization of selected Mentha species. Pak J Bot 43(3):1433-1436.

Singh TP (1995) Alteration in the basic chromosome numbers as a means of speciation in Labiatae. Feddes Repert 106(1-2):39-47.

Singh TP, Sharma AK (1986) Mentha-taxonomic status as interpreted through cytology, genetics and phytochemistry. Indian J Genet 46 (Suppl):198-208.

Sobti SN (1962) Interspecific hybrids in the genus Mentha. I. Mentha longifolia and its natural hybrids in NorthWestern Himalayas. Proc Indian Acad Sci (Sec B) 56(1): 51-55.

Sobti SN (1965) Chromosome numbers in species of Mentha. Proc Indian Acad Sci (Sec B) 62:145-148.

Sobti SN (1971a) Interspecific hybrids in the genus Mentha. I. Mentha longifolia (Linn) Huds. $\times$ M. rotundifolia Linn. Cytologia 36:121-125.

Sobti SN (1971b) Interspecific hybrids in the genus Mentha. II. Mentha arvensis Linn. $\times$ M longifolia (Linn.) Huds. Cytol 36:304-308.

Španiel S, Marhold K, Hodálová I, Lihová J (2008) Diploid and tetraploid cytotypes of Centaurea stoebe (Asteraceae) in central Europe: morphological differentiation and cytotype distribution patterns. Folia Geobot 43: 131-158.

Srivastava DK (2012) Cytomorphological diversity in species of Labiatae and Scrophulariaceae from Lahaul Spiti and adjoining areas. PhD Thesis, Department of Botany, Punjabi University Patiala, Punjab (India).
Stebbins GL (1950) Variation and Evolution in Plants. Columbia University Press, New York. 643 pp.

Štěpánek J (1993) Mentha L. - Mäta. In Bertová L, Goliašová K, ed., Flóra Slovenska V/1. Veda, Bratislava. 375-394.

Stout JC, Duffy KJ, Egan PA, Harbourne M, Hodkinson TR (2015) Genetic diversity and floral width variation in introduced and native populations of a long-lived woody perennial. AoB Plants 7:plu087.

Stuessy TF, Jakubowsky G, Salguero-Gómez R, Pfosser M, Schluter PM, Fer T, Sun BY, Kato H (2006) Anagenetic evolution in island plants. J Biogeogr 33:1259-1265.

Suzuka O, Koriba S (1949) Chromosome numbers of medical plants. I. Jap J Pharmacogn 3:68-74.

Svensson S (1983) Chromosome numbers and morphology in the Capsella bursa-pastoris complex (Brassicaceae) in Greece. Willdenowia 13:267-276.

Tarimcilar G, Kaynak G (2004) Chromosome counts in some Anatolian species of Mentha (Labiatae). Flora Medit 14:253-262.

Tischler G (1934) Die Bedeutungen der Polyploidie für die Verbreitung der Angiospermen erläutert an den Arten Schleswig-Holsteins, mit Ausblicken auf andere Florengebiete. Bot Jahrbuch 67:1-36.

Tsuda C (1954) Cytological studies on the genus Mentha. I. On the meiosis in M. rotundifolia (L.) Huds. (Japanese with English resume) Japan J Breed 3:7-14.

Uhrikova A (1978) Index of chromosome numbers of Slovakian flora. Part 6. Acta Fac Rerum Nat Univ Comen Bot 26:1-42.

Valen LV (1965) Morphological variation and width of ecological niche. Am Nat 99(908):377-390.

White F (1971) The taxonomic and ecological basis of chorology. Mitt Bot Staatssamml München 10:91-112.

Whittaker RJ, Fernández-Palacios JM (2007) Island Biogeography: Ecology, Evolution and Conservation. Oxford University Press, Oxford, UK.

Zhukova PG (1967) Karyology of some plants cultivated in the Arctic-Alpine Botanical Garden. In Avrorin NA, ed., Plantarum in Zonam Polarem Transportatio II. Leningrad 139-149. 
